\title{
REVITALISASI PASAR SENI DAN WISATA GABUSAN
}

\author{
A. A. Ayu Ratih T.A.K ${ }^{1}$, Anna Pudianti ${ }^{2}$, V.R. Vitasurya ${ }^{3}$ \\ Program Studi Arsitektur, Fakultas Teknik \\ Universitas Atma Jaya Yogyakarta \\ Email: ayu.ratih@uajy.ac.id
}

\begin{abstract}
An art market is a place where producers and consumers meet with various arts as its main item. Meanwhile, a tourism destination is a place where it should contain 3 main elements: attraction, amenity, accommodation. Tourism Gabusan Art and Cultural Market in Bantul, Yogyakarta experience a degradation of its quality as the market as well as a place for accommodating arts. One of its main causes is its lack of visibility or visual quality or image toward its area. So that, this should be further analyzed and revitalized from an architectural and urban design point of view. Revitalization is an effort to enhance a land or region's value through rebuilding or reconstruction of its area. The imageability approach by Kevin Lynch will be used in this research by using five-city elements in Gabusan Art Market with SWOT analysis. The research method is a comparative study by using data from literature review and observations. The result of this research was used as a reference to redesign Gabusan Art Market to achieve optimal visual quality. Masterplan of Gabusan Art and Cultural Market in Bantul, Yogyakarta was produced as a final product, along with the development strategy to cope with the challenges of tourism attraction.
\end{abstract}

Keywords: Market, Art, Gabusan, Visual Quality, Image

\begin{abstract}
Abstrak. Pasar seni adalah tempat jual beli dan bertemunya produsen dan konsumen dengan barang atau jasa yang ditawarkan berupa berbagai hasil karya seni. Sedangkan tempat wisata adalah tempat yang memiliki 3 aspek pokok yaitu atraksi, amenitas, dan akomodasi. Pasar Seni dan Wisata Gabusan (PSWG) di Kabupaten Bantul, Yogyakarta mengalami penurunan kualitas sebagai destinasi seni dan wisata di Yogyakarta. Salah satu penyebab utama adalah kualitas visual Pasar Seni dan Wisata Gabusan yang kurang menarik dan perlu direvitalisasi dari segi arsitektur dan kawasan. Revitalisasi adalah upaya untuk meningkatkan nilai lahan/kawasan melalui pembangunan kembali dalam suatu kawasan yang dapat meningkatkan fungsi kawasan sebelumnya. Pendekatan analisis kualitas visual atau citra kawasan yang dipakai adalah teori imageability oleh Kevin Lynch dengan parameter kelima elemen perkotaan di kawasan Pasar Seni dan Wisata Gabusan. Metode dalam pengabdian ini adalah studi komparasi (perbandingan) dengan studi kasus dan analisis SWOT lalu menggunakan strategi revitalisasi. Pengambilan data dengan studi literatur dan observasi kawasan. Hasil analisis menjadi acuan dalam mendesain ulang Pasar Seni dan Wisata Gabusan agar lebih menarik dan tertata secara visual. Masterplan revitalisasi Pasar Seni dan Wisata Gabusan merupakan produk akhir yang disertai pula dengan strategi pengembangan untuk menjawab tantangan meningkatkan daya tarik obyek wisata,
\end{abstract}

Kata kunci : Pasar, Seni, Gabusan, Kualitas Visual, Citra

\section{PENDAHULUAN}

\section{Perkembangan Pasar Seni dan Wisata Gabusan}

Tren pariwisata di Yogyakarta khususnya

di daerah Bantul mengalami pergeseran. Sebelumnya wisatawan berkunjung hanya untuk menikmati pengalaman saat datang ke destinasi wisata. Namun kini, selain berkunjung, wisatawan juga mementingkan citra kualitas visual suatu destinasi wisata. Tujuannya agar dapat berbagi, salah satunya dengan mengunggah ke media sosial dan berbagi pengalaman dengan teman, kerabat, dan masyarakat umum mengenai pengalaman wisata tersebut. Perubahan perilaku wisatawan ini perlu menjadi perhatian khusus dalam pembuatan dan pengembangan destinasi wisata. Wisatawan umumnya telah memiliki agenda dan jadwal sendiri saat berkunjung.

Pasar Seni Gabusan terletak di Jalan Parangtritis km. 9.5, Kecamatan Sewon, Kabupaten Bantul. Saat ini, Pasar Seni Gabusan berperan sebagai amenitas dan atraksi yaitu fasilitas penunjang cinderamata dan kesenian, serta dapat menampung acara (akomodasi) terkait dengan kesenian, kerajinan, cinderamata, dan pariwisata Bantul. Menurut BPS Kabupaten Bantul 2018, Industri Kecil dikuasai oleh 3 sektor yaitu pengolahan pangan, kerajinan umum, dan kimia-bahan bangunan. Sedangkan untuk bidang 
ekspor, jenis komoditas yang paling banyak diekspor adalah Kerajinan Kayu dan Meubel Kayu Jumlah perusahaan berbadan hukum Kecamatan Sewon menduduki peringkat kedua tertinggi di Kabupaten Bantul. Akomodasi berupa hotel dan restoran di Kecamatan Sewon juga tercatat memiliki jumlah tertinggi di Kabupaten Bantul. Tercatat ada 3.584 .988 pengunjung tahun 2018 di 7 Objek Wisata Alam (Pantai Parangtritis, Pantai Samas, Goa Cemara, Pantai Pandansimo, Pantai Kuwaru, Goa Selarong, Goa Cerme) di Bantul. Hal ini mengindikasikan tingginya minat wisatawan untuk mengunjungi Bantul (BPS KabupatenBantul, 2020)

Pasar Seni dan Wisata Gabusan (PSWG) didirikan pada tahun 2004 sebagai tempat jual beli produk seni. PSWG dirancang oleh Ir.Ikaputra, M.Eng., IAI dengan konsep lokalitas. Terdapat 5 idiom sebagai konsep yang diterapkan dalam desain PSWG yaitu lokalitas bentuk, lokalitas suasana, lokalitas gerak, lokalitas ide, dan lokalitas spirit. Lokalitas bentuk, terinspirasi dari bentuk tobong atau tempat pembakaran gerabah. Lokalitas suasana yaitu interaksi sosial yang terjadi di pasar tradisional dengan penggunaan skala manusia pada bangunan pasar. Ide berikutnya yaitu lokalitas gerak yang menekankan pada kedinamisan aksesibilitas termasuk bagi penyandang difabel. Lokalitas ide yaitu mengangkat kesenian rakyat setempat. Yang terakhir yaitu lokalitas spirit. Lokalitas spirit maksudnya adalah dengan mengembalikan pasar ke esensi sesungguhnya sebagai tempat berbagai kalangan bertemu. (Ikatan Arsitek Indonesia., 2005)

Pasar yang digiatkan oleh 18.000 pengrajin dan 25 desa sentra industri kerajinan bertujuan sebagai media pemberdayaan ekonomi daerah. Media pemberdayaan ekonomi daerah juga berfungsi sebagai pusat rekreasi keluarga di daerah selatan Kota Jogjakarta sekaligus mengakomodasi kebutuhan bisnis kerajinan, wisatawan, keluarga, serta komunitas kreatif berbasis tradisional. (Ikatan Arsitek Indonesia., 2005). Tatanan fisik pada awal perencanaan PSWG dirancang mengakomodasi fungsi dan aktivitas dalam 6 zona seperti terlihat pada Gambar 1 di bawah ini:

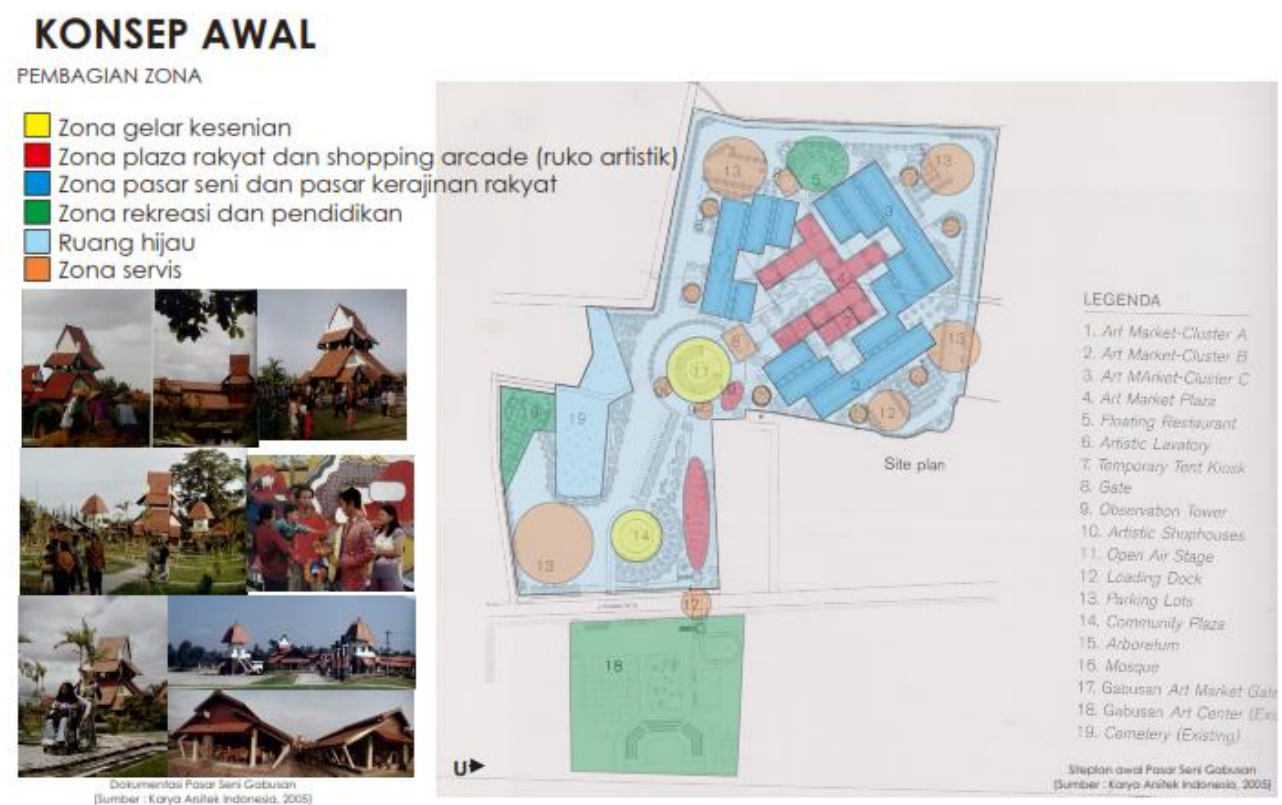

Gambar 1. Desain Awal Pasar Seni Gabusan tahun 2003-2004, Sumber : disadur dan diedit dari Karya Arsitek Indonesia,2005:124

Seiring dengan perubahan waktu dan tren, Pasar Seni Gabusan mengalami kondisi memprihatinkan sekitar tahun 2009. Hal ini diindikasikan dengan menurunnya jumlah wisatawan yang berkunjung ke tempat tersebut sehingga disimpulkan bahwa Pasar Seni Gabusan kini telah berubah suasana dan aktivitasnya dari tujuan awal. (Kompas, 2009). Kondisi ini 
membutuhkan upaya revitalisasi sebagai langkah untuk mengembalikan keberadaan PSWG pada tujuannya. Untuk merevitalisasi Pasar Seni Gabusan memerlukan proses dan strategi yang tepat. Hal ini disebabkan karena kesuksesan pariwisata sangat terkait dengan simbiosis antarperlaku wisata yaitu pemilik usaha tur wisata, pengusaha oleh-oleh dan cinderamata, wisatawan. Sepinya aktivitas di pasar ini juga dipersulit dengan adanya pandemi Covid-19. Gambaran eksisting PSWG saat ini dapat dilihat pada Gambar 2.

\section{Kondisi Pasar Seni dan Wisata Gabusan Kini: Hipotesis Masalah Utama}

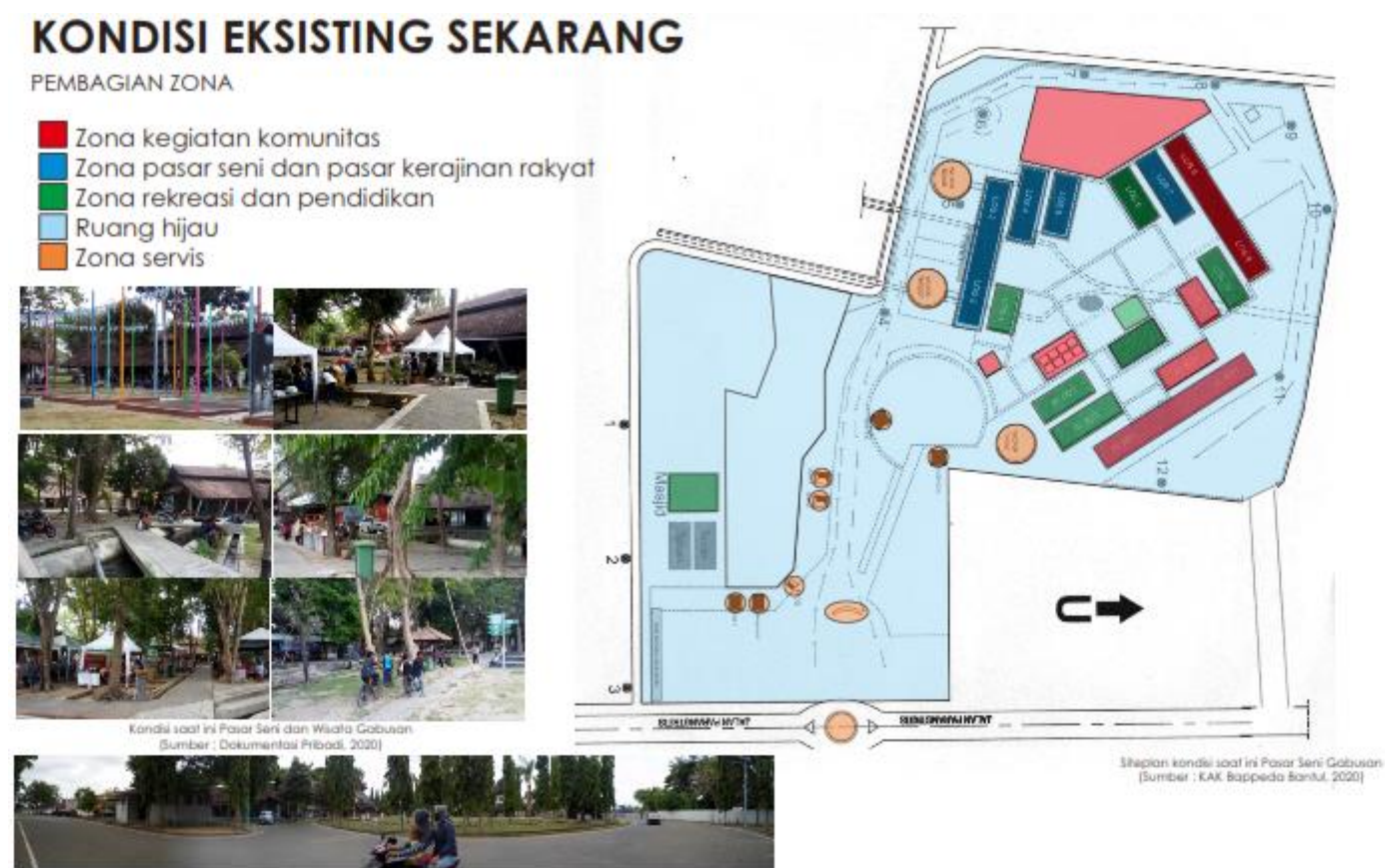

Gambar 2. Kondisi Eksisting Pasar Seni dan Wisata Gabusan, Bantul.

Sumber : disadur dan diedit dari disadur dan diedit dari Karya Arsitek Indonesia,2005:124

Pasar Seni dan Wisata Gabusan (PSWG) memiliki letak yang strategis dan berperan sebagai wadah pemasaran berbagai potensi wisata dan kesenian Bantul yang memiliki peran positif bagi sektor wisata di Kabupaten Bantul. Namun dengan adanya perkembangan jaman, berbagai permasalahan, dan kondisi pandemi Covid-19 saat ini, PSWG perlu berbenah dan membuat penyesuaian, salah satunya melalui rebranding Pasar Seni Gabusan dengan meredesain layout masterplan. Hal ini didukung juga dengan peran PSWG sebagai salah satu program strategis Pemerintah Bantul.

Kondisi terkini PSWG dapat dilihat dari dua faktor yaitu fisik dan nonfisik. Kondisi fisik yang menjadi permasalahan meliputi ikon PSWG kurang menarik, vegetasi eksisting adalah pepohonan tinggi, dan penataan layout aktivitas yang kurang tertata. Faktor nonfisik berupa kurangnya promosi, dan mayoritas masyarakat datang ke PSWG jika ada kegiatan komunitas saja. Hal ini menyebabkan berkurangnya jumlah pengunjung, kegiatan komunitas lebih dominan daripada kegiatan seni dan jual beli kerajinan, kurang tertatanya lingkungan dengan banyaknya parkir liar di seluruh sudut kompleks.

Pasar Seni dan Wisata Gabusan sebagai ruang publik harus mampu menyesuaikan perkembangan kondisi termasuk menata ruang, kemajuan teknologi, dan memperhatikan penerapan protokol kesehatan. Oleh karena itu, perlu penambahan sarana dan prasarana untuk mewujudkan kawasan adaptif, higienis, edukatif, kreatif, dan representatif. Sasaran pengunjung utama adalah keluarga, anak muda kreatif, dan wisatawan dalam dan luar negeri. Untuk pengembangan jangka panjangnya, diharapkan Pasar Seni Gabusan tidak hanya menjadi tempat UMKM cinderamata, makanan, kerajinan Khas Bantul, tetapi juga dapat menjadi wadah kegiatan seni berskala nasional dan internasional serta 
menjadi ruang publik yang menyenangkan dan layak bagi masyarakat sekitar.

Universitas Atma Jaya Yogyakarta memiliki peran untuk interaksi dan edukasi pada masyarakat sebagai salah satu bentuk pengabdian. Salah satu kewajiban tenaga pendidik selain sebagai pengajar juga mengabdikan ilmu yang dimiliki pada masyarakat. Hal ini dilakukan khususnya dalam aplikasi ilmu desain arsitektur dan kawasan di program Pengabdian Rebranding Pasar Seni Gabusan dalam bidang kearifan lokal. Eksistensi Pasar Seni dan Wisata Gabusan sebagai wadah interaksi seni dan produk seni perlu dihidupkan kembali sesuai dengan spirit awal saat dibangun yaitu lokalitas.

\section{METODE PELAKSANAAN}

Metode yang digunakan dalam pengabdian ini melalui studi kasus dengan studi literatur dan observasi sebagai tahap awal penelitian. Hasil studi digunakan menjadi acuan selanjutnya dalam mendesain Kawasan Pasar Seni dan Wisata Gabusan, Bantul. Parameter yang dinilai menggunakan teori elemen perkotaan oleh Lynch yaitu path, landmark, district, nodes dan edges dengan penjelasan deskriptif dengan metode tabulasi Strength Weakness Opportunity Threat (SWOT).

Metode pelaksanaan dibagi menjadi 3 tahap yaitu Tahap 1, Tahap 2 dan Tahap 3. Secara skematik, metode pelaksanaan pengadian ini dapat dilihat pada gambar 3. Tahap 1 adalah pengumpulan data terkait profil amatan, tahap 2 adalah identifikasi masalah dan potensi amatan, dan tahap 3 adalah pembuatan produk berupa publikasi . Diskusi dilakukan dalam berbagai bentuk yaitu wawancara tak terstruktur, rapat internal, rapat dengan mitra (Badan Perencanaan Pembangunan, Penelitian dan Pengembangan Daerah (Bappeda) Bantul) sebagai proses menggali informasi potensi dan masalah sebagai referensi mendesain.

Mitra kegiatan ini ada beberapa pihak yaitu 1) Bappeda Bantul sebagai pihak yang menginisiasi kegiatan pengabdian pada masyarakat, 2) Dinas Perindustrian, Perdagangan, Koperasi dan UKM sebagai pengelola Pasar Seni dan Wisata Gabusan, serta pihak yang menjembatani komunikasi antara pengusaha, pemerintah dengan tim pengabdian. Pemberdayaan diberikan kepada pemangku kepentingan (stake holder) dalam bentuk keikutsertaan mereka dalam mengusulkan gagasan/ ide revitalisasi pada bidang masingmasing bertujuan membuat program strategis untuk 5 tahun ke depan. Pemangku kepentingan pada Pasar Seni dan Wisata Gabusan ini adalah para penyewa/penjual, seniman, komunitas pengguna ruang di PSWG.

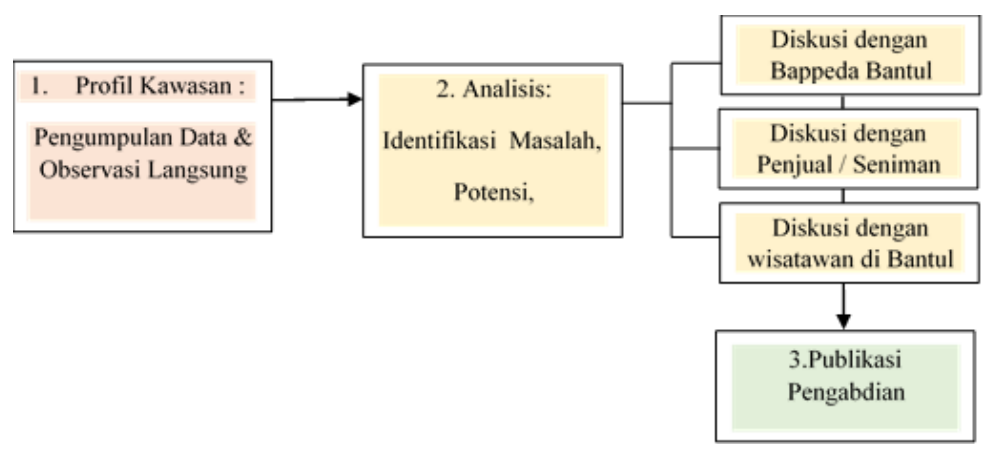

\section{Tahap 1}

Pengumpulan data profil kawasan dengan data primer dan data sekunder. Data Primer berupa survey dan observasi kawasan dan data sekunder berupa studi literatur (buku, artikel, berita, jurnal) terkait dengan Pasar Seni Gabusan.

\section{Tahap 2}

Identifikasi masalah dan potensi kawasan yang dilakukan dengan diskusi dengan Bappeda 
Bantul, Diskusi dengan penjual atau seniman dan wisatawan sebagai pelaku kegiatan di kawasan. Identifikasi masalah dan potensi kawasan dilakukan dengan analisis SWOT (Strength
Weakness Opportunity Weakness) menggunakan parameter dengan kelima elemen perkotaan teori Kevin Lynch (five city elements). (lihat Tabel 1)

Tabel 1. Teknik Analisis SWOT

\begin{tabular}{lcc}
\hline & $\begin{array}{c}\text { Kekuatan Internal } \\
(\text { S-Strength })\end{array}$ & $\begin{array}{c}\text { Kelemahan Internal } \\
(\text { W-Weakness })\end{array}$ \\
\hline $\begin{array}{l}\text { Kekuatan Eksternal : } \\
\text { Peluang }(\boldsymbol{O} \text {-Opportunity) }\end{array}$ & Strategi SO & Strategi WO \\
\hline $\begin{array}{l}\text { Kelemahan Eksternal: } \\
\text { Tantangan }(T-\text { Threat })\end{array}$ & Strategi ST & Strategi WT \\
\hline
\end{tabular}

Teknik analisis SWOT adalah metode awal untuk mengevaluasi suatu kasus menggunakan 4 elemen yaitu kekuatan ( $S$ Strength), kelemahan (W-Weakness), Peluang (OOpportunity), Ancaman (T-Threat). Strength adalah kekuatan yang berasal dari internal suatu kasus contohnya seperti produk dan jasa yang memiliki reputasi bagus, manajemen perusahaan yang tertata baik, prestasi perusahaan di berbagai konteks. Weakness adalah kelemahan internal contohnya gaji dan bonus yang kecil, tidak adanya fasilitas bagi karyawan, minimnya penjualan suatu perusahaan. Opportunity adalah peluang yang berasal faktor luar contohnya banyaknya pengunjung ke suatu tempat usaha sehingga menjadikan tempat tersebut terkenal. Threat merupakan ancaman yang berasal dari faktor luar suatu kasus amatan contohnya muncul tempat usaha serupa di sekitar dan lebih banyak pengunjungnya sehingga menimpulkan kompetisi. Analisis ini digunakan untuk menemukan strategi terbaik dari sebuah kasus atau obyek amatan tertentu. Hasil silang berupa strategi SO (Strength-Opportunity), ST(StrengthThreat), WO (Weakness-Opportunity), WT (Weakness-Threat).

\section{Tahap 3}

Publikasi pengabdian berupa penulisan jurnal ilmiah sebagai tahap awal penelitian dan studi literatur. Pada tahap ini mengenai hasil analisis keseluruhan dari tahap awal seperti pengumpulan data hingga tahap analisis dan kesimpulan sementara (hipotesis). Setelah melakukan analisis dan evaluasi awal melalui SWOT maka ditemukan hipotesis atau hasil analisis sementara. Hasil ini maka dituliskan pada karya ilmiah berupa jurnal sebagai dasar untuk mendesain ke tahap selanjutnya. Dari seluruh proses ini maka dibuat strategi awal untuk mendesain masterplan yang bersifat acuan.

\section{Waktu Pelaksanaan, Alat dan Bahan}

Seluruh proses dilakukan hybrid melalui sistem daring dan beberapa kali luring karena kondisi pandemi sehingga tidak memungkinkan untuk bertatap muka langsung dengan intens. Proses penelitian untuk mendukung aktivitas pengabdian dilakukan dari Oktober 2020 Februari 2021 menggunakan berbagai program bantuan seperti Microsoft Office (Ms.Word), Ms. Teams dan WhatsApp sebagai media komunikasi, berbagai website dan E-book untuk melakukan studi literatur, dan Google Earth Map untuk melakukan survey secara daring.

\section{HASIL DAN PEMBAHASAN}

Hasil dari pengabdian berupa pedoman dalam bentuk masterplan untuk panduan pengembangan pembangunan. Berikut ini adalah rincian penjelasan dari hasil pengabdian :

\section{Analisis Site dengan 5 elemen perkotaan Kevin Lynch}

Legibilitas atau visibilitas adalah pengenalan kawasan melalui evaluasi identitas, struktur, dan makna melalui kelima elemen perkotaan yaitu path, edges, landmark, district, dan nodes. $\quad$ Path adalah jalur yang dilalui. Jalur ini dapat berupa ruang jalan, jalur pedestrian, jalur sepeda, jalur kereta api, tepi sungai yang bersifat mengarahkan, dan memiliki pelingkup kawasan. Edges adalah batas suatu kawasan bersifat memisahkan, membatasi, dan tidak bisa 
dilalui oleh pedestrian. Batas ini dapat berupa jalan utama, sungai, jalur keretaapi. Landmark merupakan penanda dan acuan kawasan yang unik, mecolok pada skala dan bentuknya memiliki makna tertentu dan berada lokasi strategis. District yaitu susunan suatu kawasan yang memiliki kecenderungan fungsi serupa, hal ini dapat dilihat dari pola solid-void pemetaan kawasan. Nodes adalah titik simpul sebagai tempat berkumpul aktivitas manusia. Nodes dapat berupa perempatan jalan, plaza. Nodes memiliki 2 sifat yaitu mengarahkan dan tidak mengarahkan (Lynch, 1960). Dari kelima elemen perkotaan, path dan landmark merupakan bagian yang terintegrasi penuh terhadap citra kota.(McCunn, L. J., \& Gifford, 2018). Berikut ini adalah analisis Pasar Seni dan Wisata Gabusan menggunakan elemen perkotaan Kevin Lynch:

\section{a. Path}

Path atau jalur di sekitar PSWG adalah Jalan Parangtritis sebagai akses utama menuju destinasi, Jalan Lingkungan yang terletak mengelilingi site, Jalan akses di dalam site berupa jalur kendaraan bermotor (warna biru), dan jalur pedestrian dan sepeda (warna hijau)Lihat Gambar 4. Kualitas visual PSWG sebagai tempat wisata kurang optimal dari Jalan Parangtritis. Adanya bundaran di depan pintu masuk, cukup membantu untuk memusatkan konsentrasi pengendara dan pengunjung untuk fokus ke PSWG namun hal ini kurang didukung dengan kualitas visual di area pintu masuk utama (Lihat Gambar 5). Jalan akses di dalam site berupa paving block dan penghijauan di sekeliling. Namun karakter penghijauan belum mengarahkan pengunjung sehingga hal ini dapat menjadi masukan untuk menata lanskap sekitar yang selain indah juga bersifat mengarahkan

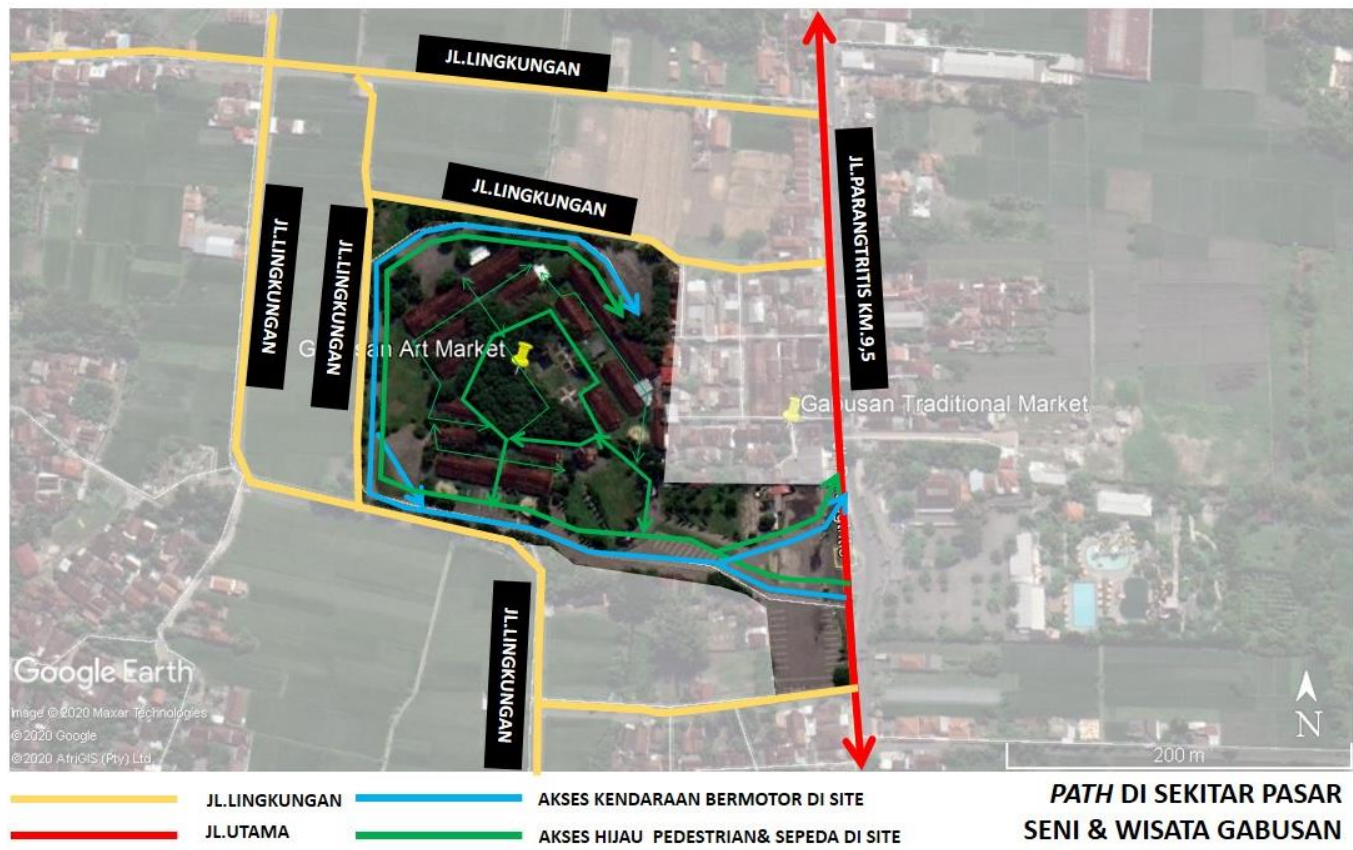

Gambar 4. Analisis Path Pasar Seni dan Wisata Gabusan Gambar 5. (kiri) Kondisi Pintu Masuk PSWG, (kanan) Jalan Pintu Masuk PSWG
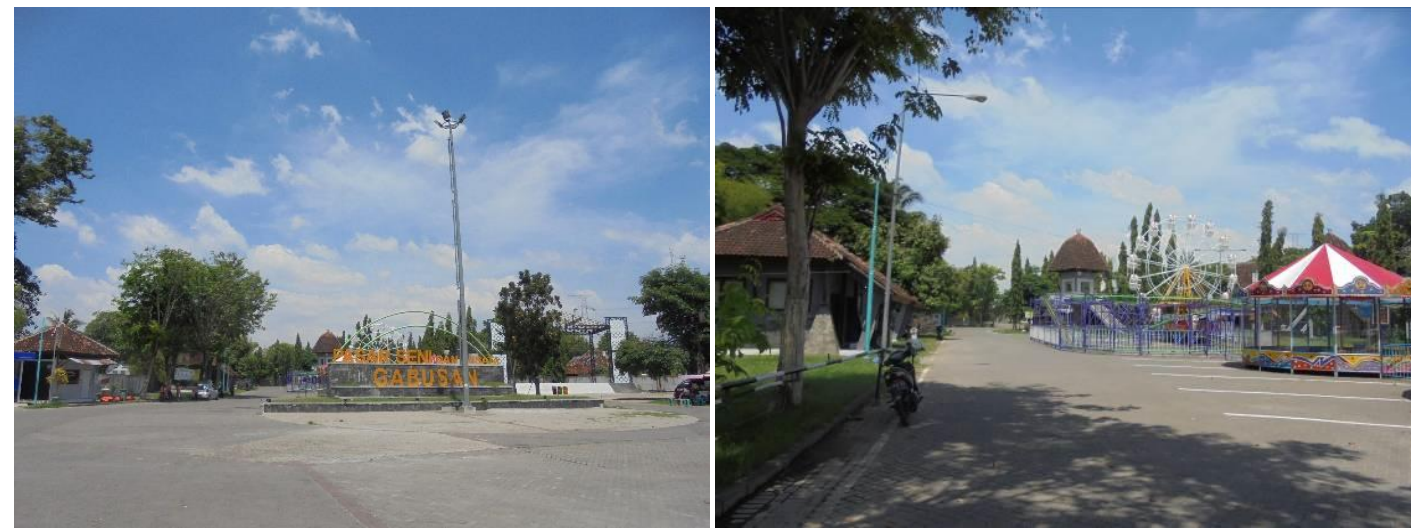
b. Edges

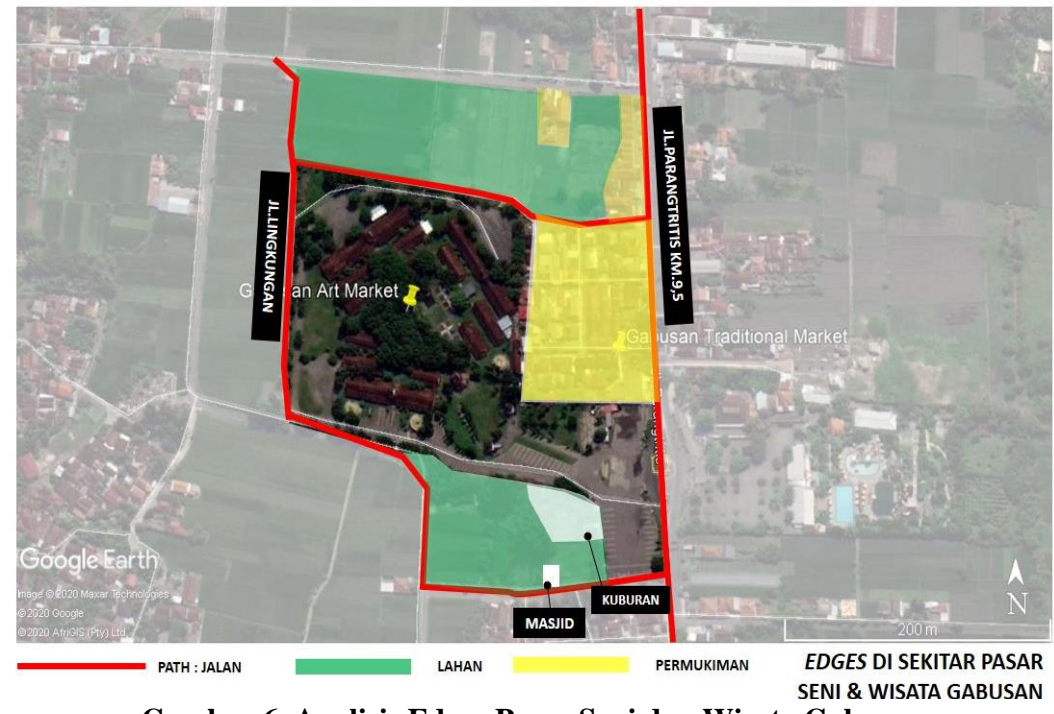

Gambar 6. Analisis Edges Pasar Seni dan Wisata Gabusan

Edges atau pembatas kawasan di sekitar PSWG berupa jalan, distrik permukiman, dan lahan hijau yang berupa ladang dan sawah. Di sisi selatan site, ada tempat pemakaman dan masjid yang saling berdampingan, di seberang timur site ada Jalan Parangtritis dan ada lahan yang dulu adalah Bagian dari PSWG, sekarang merupakan tempat wisata Grand Puri Waterpark (lihat Gambar 6).

\section{c. Landmark}

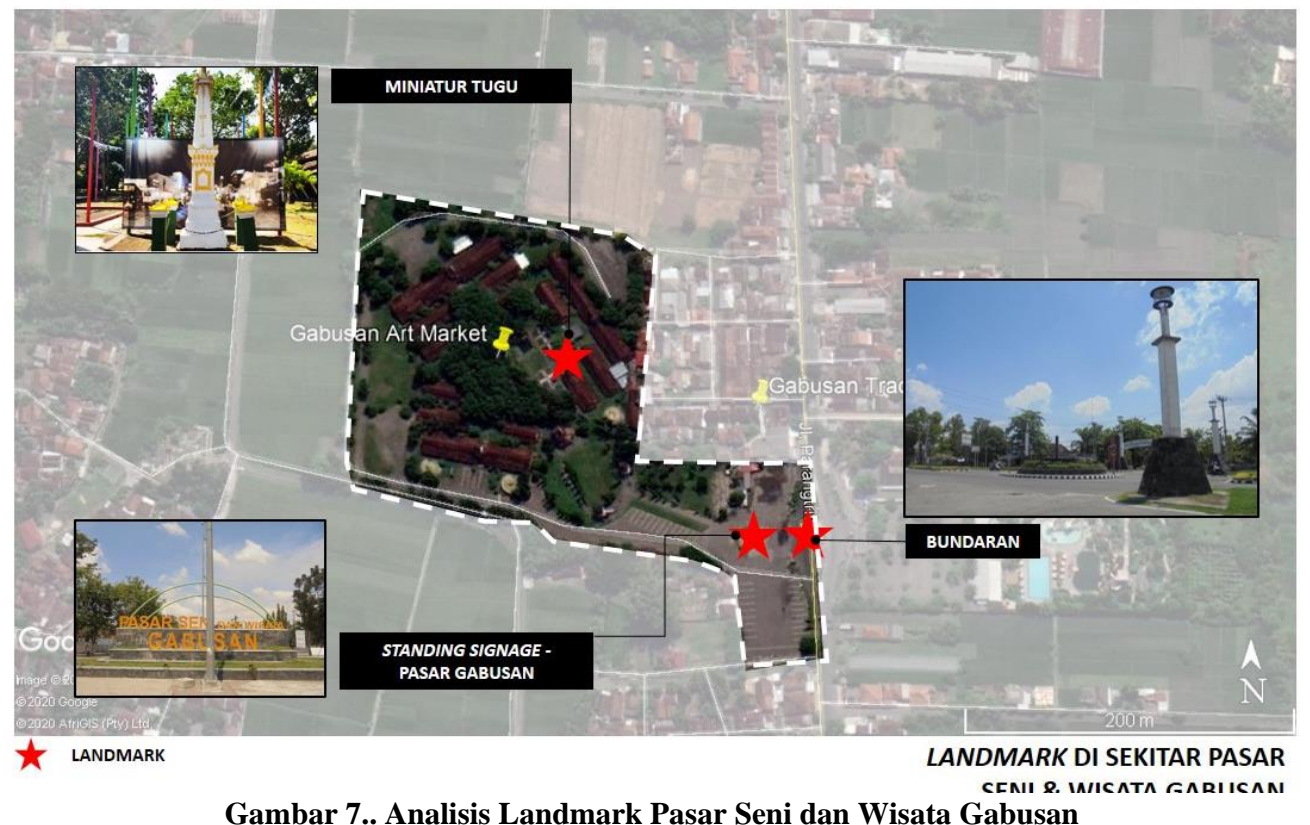

Landmark atau penanda di Kawasan PSWG ada 3 yaitu Bundaran di Area Pintu Masuk, Signage atau penanda berupa tulisan
Pasar Seni Gabusan, dan miniatur Tugu Yogyakarta. Area Bundaran dan signage tulisan bertujuan untuk memberi informasi pengunjung 
mengenai identitas tempat yang saat ini kurang tersajikan dengan optimal.(Lihat Gambar 7). Sedangkan Miniatur Tugu di dalam Kompleks PSWG menandakan bahwa PSWG membutuhkan suatu brand atau ikon unik sebagai tempat yang fotogenik sehingga nantinya dapat menjadi souvenir foto bagi pengunjung. Syarat utama landmark adalah tercapainya kontras secara spasial. Hal ini dapat dicapai dengan 2 cara yaitu peletakan spasial, atau adanya kontras terhadap kawasan baik dari skala, bentuk warna, usia, letak. Landmark eksisting yang saat ini ada, belum optimal dari segi kontras. Hal ini dapat menjadi peluang renovasi agar dapat memperkuat wajah dan identitas PSWG di masa mendatang. d. District

District di sekitar PSWG sebagian besar berupa lahan hijau, permukiman, dan komersial. Lahan Hijau berupa ladang, sawah, Permukiman adalah konstelasi hunian warga, baik dalam bentuk perumahan, maupun rumah individual tanpa gerbang perumahan, komersial berupa restoran, rumah makan, warung, bank, dan badan usaha lainnya (lihat Gambar 8). Di dalam kompleks PSWG sendiri, kumpulan bangunan sebagian besar terdiri dari bangunan losmen (untuk berdagang),panggung, tempat menyimpan peralatan, dan fasilitas pendukung seperti toilet, tempat tiket. (Gambar 9).

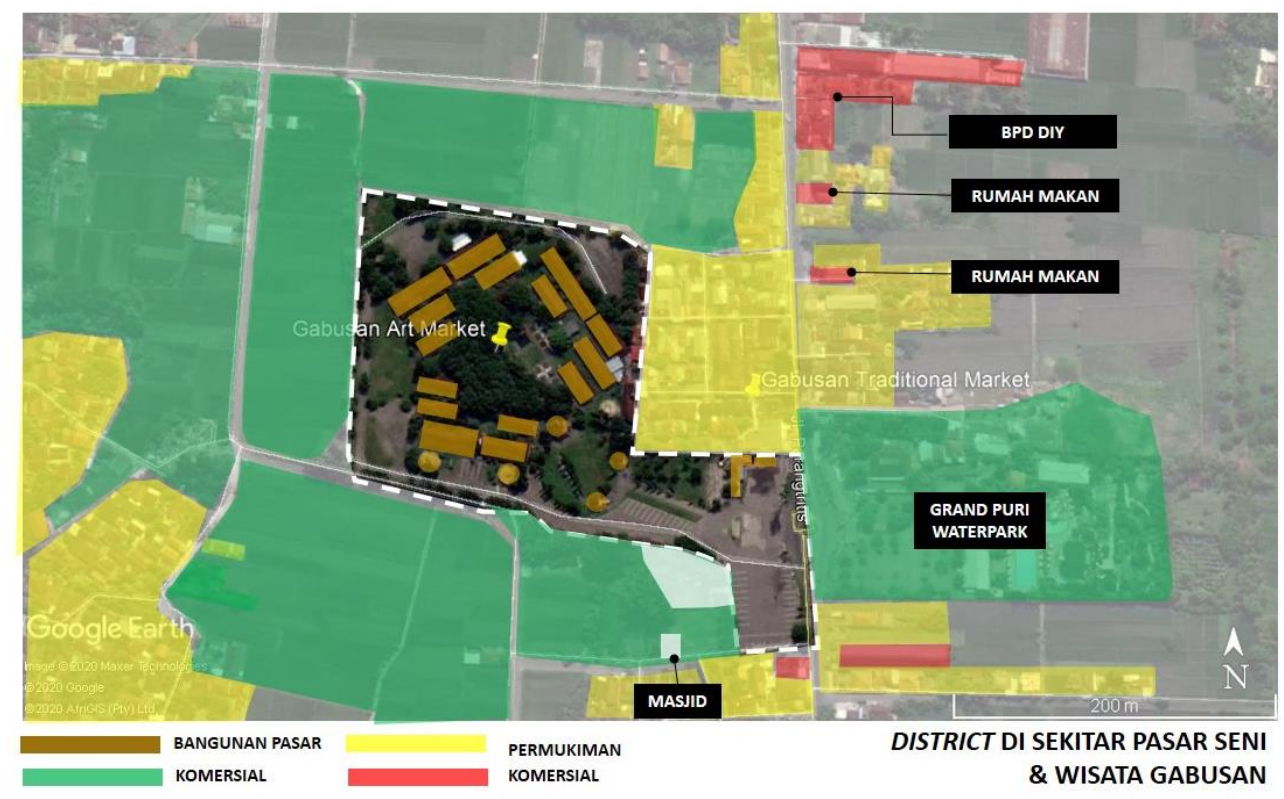

Gambar 8. Analisis District Pasar Seni dan Wisata Gabusan

Gambar 9. (kiri) Bangunan Losmen, (kanan) Area Penyimpanan Gamelan \& Toko

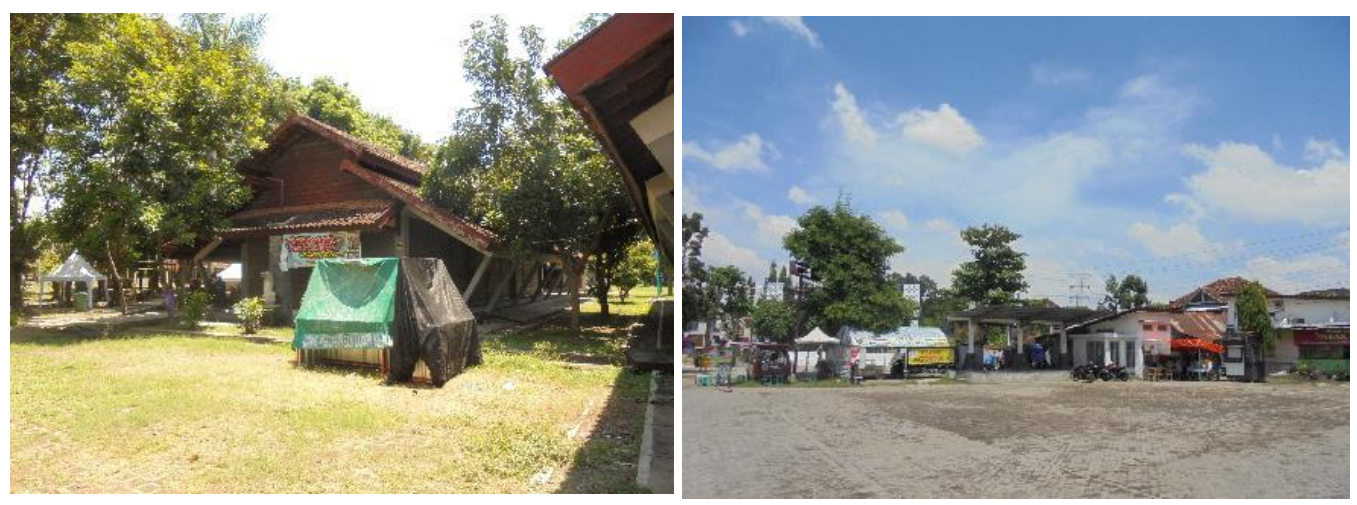




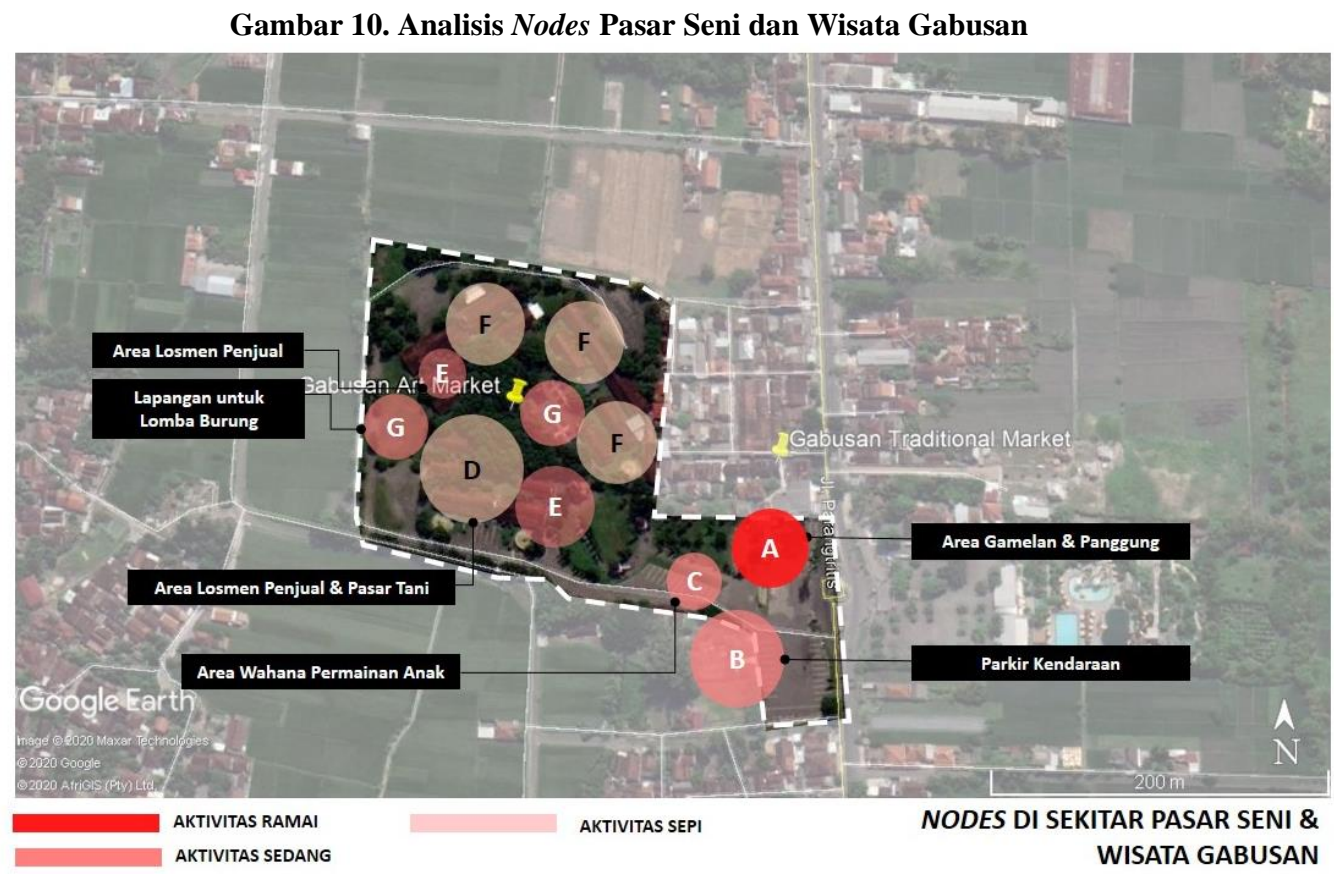

e. Nodes

Nodes adalah simpul aktivitas di suatu kawasan. Sebagai tempat publik dan tempat berkumpul, PSWG belum mencapai titik optimalnya. Namun pada kesehariannya, di beberapa titik sudah menjadi tempat berkumpul bagi beberapa kalangan. Pada gambar 10, tertera sebaran aktivitas sesuai gradasi nya yaitu ramai-sedang-sepi. Area A adalah tempat gamelan dan ada beberapa pertokoan yang sering menjadi tempat berkumpul warga sekitar. Area B merupakan parkir on-street sehingga area ini sebetulnya bukan area parkir tetapi dijadikan tempat parkir oleh mobil, sepeda motor, maupun sepeda (komunitas pesepeda). Melihat aktivitas area $\mathrm{B}$, menandakan bahwa PSWG juga berpotensi sebagai area transit bagi warga yang dari area selatan (Pantai Parangtritis), atau menuju utara (Kota Yogyakarta).
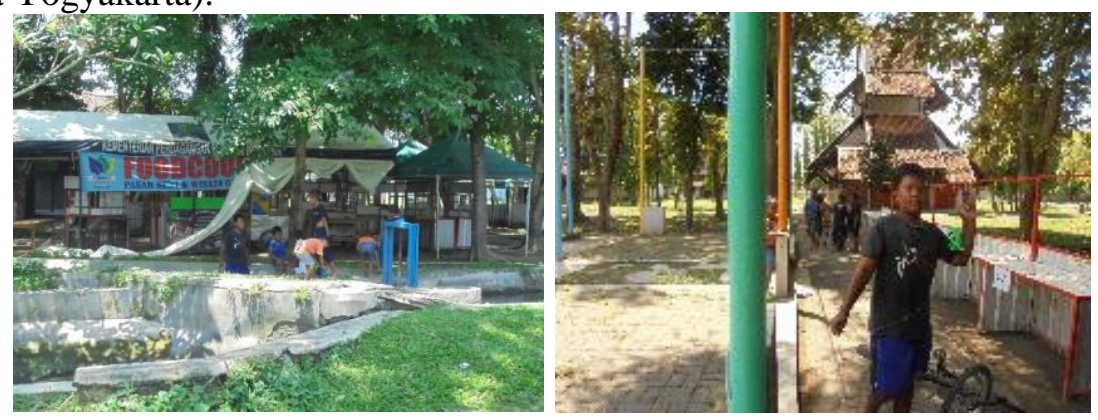

Gambar 11. Suasana PSWG siang hari weekdays wahana permainan anak-anak.Peletakan wahana di area ini kurang strategis karena terletak di titik dimana kualitas visual wajah PSWG potensial untuk dioptimalkan. Area D adalah area losmen penjual dan bersinggungan juga dengan area pasar tani, sewaktu-waktu juga di taman tengah diadakan festival sesuai tema per acara. Area E dan F adalah area pengrajin dan pedagang. Pada weekdays dan weekend area ini relatif sepi pengunjung, umumnya aktivitas berasal dari aktivitas pengrajin dan penjual di losmen itu sendiri (lihat gambar 11). Area $G$ adalah lapangan yang dipakai untuk area lomba burung. Area ini hanya ramai saat ada acara, pada kesehariannya area ini kosong, dan umumnya dipakai oleh anak-anak sekitar untuk bermain. 


\section{Analisis SWOT}

Setelah menganalisis PSWG menggunakan elemen perkotaan Lynch, maka berikut ini (Tabel

2) adalah analisis Strength Weakness Opportunity Threat (SWOT).

Tabel 2. Analisis Strength Weakness Opportunity Threat (SWOT) Pasar Seni dan Wisata Gabusan

$$
\text { Kekuatan (S: Strength) }
$$

1. Letak: Strategi berada diantara Destinasi Wisata Selatan Yogyakarta dan Kota Yogyakarta.

2. Luas: 4,3 Ha, luas yang memadai, potensi sebagai taman, plaza, dan venue berbagai acara.

3. Path: jalur kawasan sangat strategis, terletak di garis imaginer Yogyakarta (Jl.Parangtritis)

4. District: area dikelilingi oleh berbagai fungsi bangunan yang mendukung. Area Selatan Yogyakarta terkenal sebagai area seni dan pengrajin dan terletak dekat ISI Yogyakarta.

5. Bentuk bangunan : unik dan vernakular hasil karya arsitek asal Yogyakarta yaitu Ir. Ikaputra., M.Eng., Ph.D.

6. Sungai : adanya saluran sungai aliran irigasi yang dapat dikembangkan sebagai bagian dari lanskap.

7. Vegetasi : beragamnya vegetasi di lanskap site. Kelemahan (W: Weakness)

1.Kualitas Visual: walaupun letak strategis, namun penyajian kualitas visual belum kontras (mencolok) dan belum menarik bagi pengunjung dan wisatawan.

2.Area Belakang Area sisi belakang jarang tersentuh oleh pengunjung. Hal ini disebabkan pula karena area ini banyak kios dan losmen yang nonaktif sehingga alur pengunjung tidak menyeluruh.

3.Landmark: walaupun peletakan ikon kawasan sudah berada di tempat yang sesuai, namun dari segi desain, bentuk, warna, ukuran, kontras terhadap kawasan belum maksimal.

4.Vegetasi : beragamnya vegetasi di lanskap site yang belum begitu tertata

5.Parkir : walaupun sudah ada plot tempat parkir, pada praktiknya, terjadi parkir sembarangan

6.Sirkulasi : banyak paving atau pathway rusak

7.Wahana Permainan : menghalangi pandangan area pintu masuk dan terjadi penumpukan nodes atau kerumunan pengunjung, sehingga sirkulasi tidak menyeluruh sampai belakang site.

\begin{tabular}{l} 
Peluang (O: Opportunity) \\
\hline 1. Nodes: Melting Pot Seni: PSWG dapat menjadi \\
potensi sebagai tempat berkumpul dan bercampurnya \\
seniman lokal, internasional, dan wisatawan. \\
2. Nodes: sebagai tempat transit, berkegiatan, dan \\
berkumpulnya berbagai komunitas
\end{tabular}

3. Nodes: ruang hijau \& tempat bermain bagi anakanak. Melihat hasil survey dan kegiatan keseharian, cukup banyak warga sekitar dan anak-anak bermain di dalam kompleks PSWG. Hal ini menandakan akan signifikannya kebutuhan akan ruang terbuka hijau.

\section{Ancaman (T: Threat)}

1. Persaingan antartempat wisata: dengan banyaknya tempat wisata di sekeliling PSWG, dapat menjadi ancaman sepinya PSWG, Oleh karena itu, selain dari segi manajemen, maka PSWG harus meningkatkan visibilitas terhadap kawasan.

2. Kontrol dan keamanan: Karena tempat ini direncanakan dibuka untuk publik dengan bebas dan gratis, maka dapat menjadi ancaman dari segi keamanan bagi PSWG karena pengunjung tidak terkontrol.

\section{Hipotesis : Strategi Pengembangan}

Setelah melakukan analisis SWOT maka dapat dilakukan tahap hipotesis dengan analisis silang yaitu Strategi SO ( Strength-Opportunity), WO (Weakness - Opportunity), ST ( Strength Threat), dan WT (Weakness-Threat) pada Tabel 3 sebagai berikut 
Tabel 3. Strategi SWOT

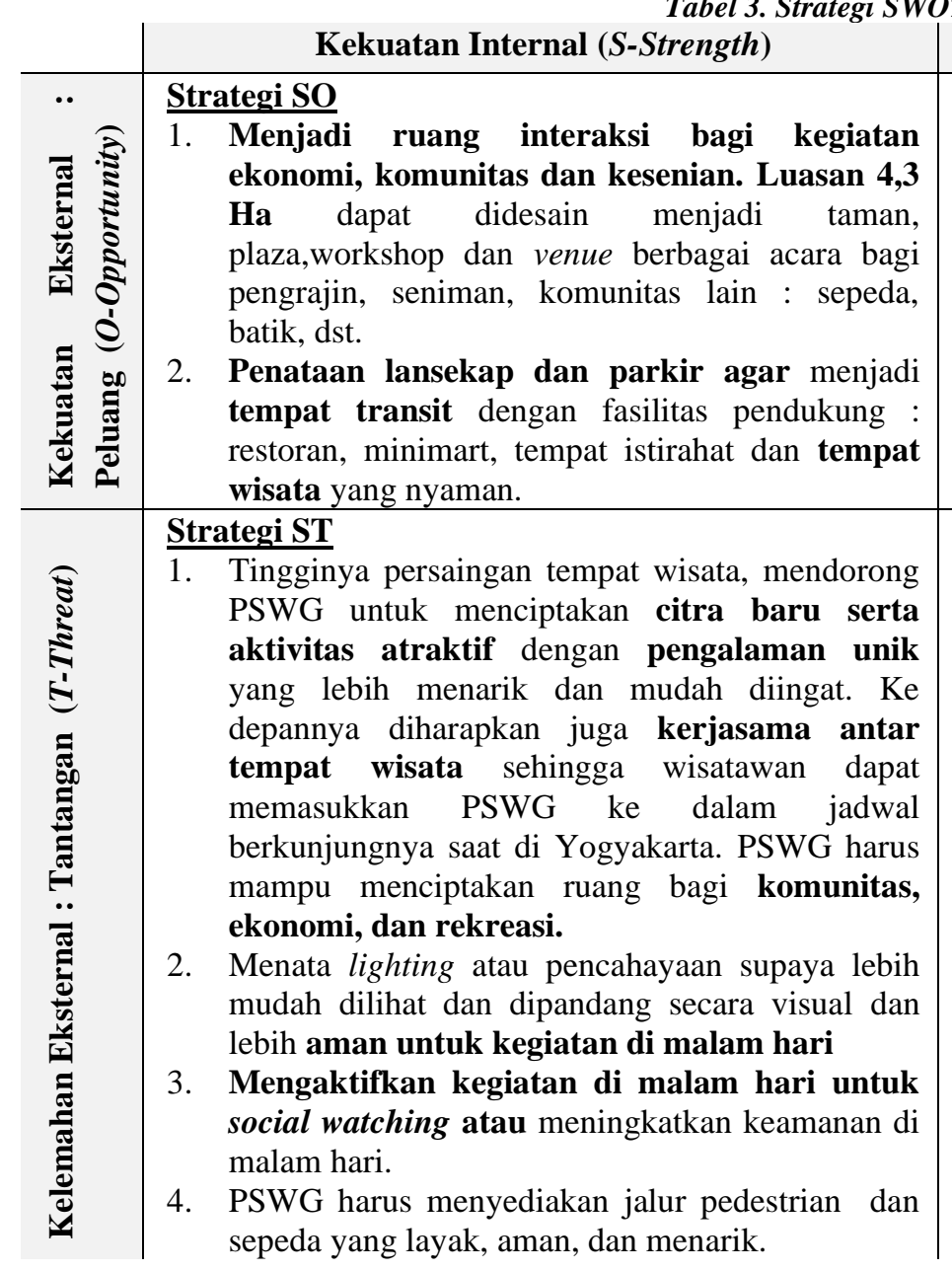

Kelemahan Internal (W-Weakness)

Strategi WO

1. Agar dapat menjadi magnet bagi berbagai kalangan dan komunitas maka harus ada renovasi dari segi kualitas visual terutama di area pintu masuk : gate, ikon/landmark, dan signage nama tempat. Area ini dapat berupa peletakan ikon/patung dan plaza sehingga menjadi ikon dan wajah bagi kawasan sekitar.

\section{Strategi WT}

1. Lemahnya kualitas visual PSWG bagi kawasan sekitar dan lemahnya kontrol pengunjung menjadi tantangan bagi manajemen PSWG dan arsitek sebagai desainer untuk mendesain area pintu masuk yang memiliki kualitas atraktif serta juga ada social control dari segi desain.

2. Menata lighting atau pencahayaan selain elemen estetika pencahayaan yang cukup sebagai kontrol keamanan kawasan

3. Relokasi area wahana permainan

\section{Preseden}

Untuk mendukung kesuksesan pariwisata, maka harus mengandung tiga A yaitu Atraksi, Aksesibilitas, dan Amenitas. Menurut UU No.10 Tahun 2009 tentang Kepariwisataan, definisi masing-masing yaitu atraksi, aksesibilitas, dan amenitas. Komponen pariwisata 3 A dibantu dengan analisis elemen perkotaan. Untuk memudahkan menciptakan branding atau image baru maka perlu dilakukan studi preseden atau proyek contoh yang serupa dengan jenis tempat wisata di Pasar Seni dan Wisata Gabusan. Untuk elemen path, edges, landmark, district sesuai dengan definisi teori, namun untuk nodes dalam hal ini diterjemahkan menjadi aktivitas yang berlangsung di masing-masing tempat dengan referensi studi literatur. Penjelasan ini dapat dilihat pada Tabel 4. 
Tabel 4. Preseden Tempat Seni dan Wisata

\begin{tabular}{|c|c|c|c|c|}
\hline & $\begin{array}{l}\text { Garuda Wisnu Kencana } \\
\text { (GWK) Cultural Park }\end{array}$ & Krishna North Bali & Pasar Seni Ancol & Kesimpulan \\
\hline $\mathbb{\Xi}$ & \begin{tabular}{lrr} 
Jalan Raya & \multicolumn{2}{c}{ Uluwatu } \\
(Kolektor & Primer & 3) \\
(Peraturan & Daerah \\
Kabupaten & Badung \\
Nomor 26 & Tahun 2013 \\
Tentang & Rencana Tata \\
Ruang & Wilayah \\
Kabupaten & Badung \\
Tahun 2013 & - & 2033, \\
2018) &
\end{tabular} & $\begin{array}{l}\text { Jalan Raya Seririt, } \\
\text { Temutus (Kelas jalan } \\
\text { IIIA-arteri/ kolektor } \\
\text { primer) } \\
\text { (Departemen } \\
\text { Perhubungan, 2004) }\end{array}$ & $\begin{array}{lr}\text { Jalan } & \text { Lodan } \\
\text { Raya,Jalan } & \text { Binaria, } \\
\text { Jalan Gerbang } & \text { Ancol, } \\
\text { Jalan Aquarium }\end{array}$ & $\begin{array}{l}\text { Semua terletak } \\
\text { berdampingan dengan } \\
\text { Jalan Akses Utama di } \\
\text { kawasan masing-masing }\end{array}$ \\
\hline 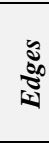 & $\begin{array}{l}\text { Ladang, Permukiman, } \\
\text { dan Jalan Raya }\end{array}$ & $\begin{array}{lr}\text { Pantai } & \text { Lovina, } \\
\text { Kompleks Permukiman } \\
\text { Temutus }\end{array}$ & $\begin{array}{l}\text { Jl.LodanRaya,Jalan } \\
\text { Binaria, J1. Gerbang } \\
\text { Ancol, J1. Aquarium }\end{array}$ & $\begin{array}{l}\text { Edges mayoritas berupa } \\
\text { jalan, dan permukiman }\end{array}$ \\
\hline 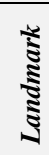 & $\begin{array}{l}\text { Patung Garuda Wisnu } \\
\text { Kencana }\end{array}$ & $\begin{array}{l}\text { Patung Penanda Krisna } \\
\text { dan Skyline Wahana }\end{array}$ & - & $\begin{array}{l}\text { Patung potensial sebagai } \\
\text { ikon kawasan }\end{array}$ \\
\hline 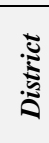 & $\begin{array}{l}\text { Permukiman, Komersil, } \\
\text { dan Ladang / Lahan } \\
\text { Hijau }\end{array}$ & $\begin{array}{l}\text { Kompleks Permukiman } \\
\text { Temutus }\end{array}$ & Kompleks Ancol & $\begin{array}{l}\text { Irisan Komersial \& } \\
\text { Permukiman }=\text { destinasi } \\
\text { wisata strategis }\end{array}$ \\
\hline 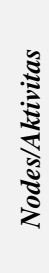 & $\begin{array}{l}\text { Menonton Pertunjukkan, } \\
\text { pameran, dan acara yang } \\
\text { diselenggarakan di } \\
\text { kompleks GWK, dan } \\
\text { bermain Segway, Jual- } \\
\text { Beli souvenir }\end{array}$ & $\begin{array}{lr}\text { Permainan } & \text { Air, } \\
\text { Wahana } & \text { Permainan, } \\
\text { Outbond, } & \text { Aktivitas } \\
\text { Kuliner, } & \text { Jual-Beli } \\
\text { souvenir } & \end{array}$ & $\begin{array}{l}\text { Menonton } \\
\text { Pertunjukkan } \\
\text { seniman, Jual-Beli } \\
\text { souvenir }\end{array}$ & $\begin{array}{l}\text { Semua memiliki aktivitas } \\
\text { utama = bagian penting } \\
\text { dari komponen pariwisata } \\
\text { Souvenir merupakan } \\
\text { penanda dan identitas } \\
\text { pernah berkunjung. }\end{array}$ \\
\hline
\end{tabular}

\section{Strategi Pengembangan: Revitalisasi}

Revitalisasi adalah upaya untuk meningkatkan nilai lahan atau kawasan melalui pembangunan kembali dalam suatu kawasan yang dapat meningkatkan fungsi kawasan sebelumny (PekerjaanUmum, 2010). Ada beberapa tipe kawasan yang dapat diselesaikan dengan strategi revitalisasi contohnya seperti kota warisan budaya (heritage town), kota lama (old town), kawasan strategis berpotensi ekonomi, permukiman kumuh, dan atau kawasan/permukiman yang vitalitasnya tidak berkembang (stagnant). Agar vitalitas tempat tersebut tidak makin memburuk, maka strategi revitalisasi perlu dilakukan hingga kawasan atau tempat terkait dapat mengalami perbaikan dan peningkatan kualitas kawasan. Pasar Seni dan Wisata Gabusan termasuk pada kawasan strategis berpotensi ekonomi yang mengalami stagnansi ekonomi dan aktivitas sehingga perlu dilakukan revitalisasi untuk memulihkan dan meningkatkan nilai tempat dan kawasan. Menurut Direktur
Jenderal Perdagangan Dalam Negeri, Oke Nurwan, program revitalisasi pasar sangat penting karena mampu meningkatkan transaksi pasar dua sampai tiga kali lipat dibandingkan sebelum revitalisasi. (Suryowati, 2016)

Ada 3 tahapan revitalisasi yaitu meliputi intervensi fisik, rehabilitasi ekonomi, dan rehabilitasi sosial. Intervensi fisik adalah upaya mengubah, meningkatkan kualitas fisik suatu tempat atau kawasan agar nilainya meningkat. Intervensi fisik dapat meliputi perbaikan street furniture, perbaikan bangunan, perbaikan, dan penyusunan serta desain ulang lanskap, perbaikan sistem penanda kawasan (signage system), mengadakan intervensi sirkulasi seperti traffic calming. Untuk mendukung intervensi fisik perlu didukung oleh rehabilitasi ekonomi dan rehabilitasi sosial. Rehabilitasi ekonomi diwujudkan melalui tersedianya fungsi campuran di suatu kawasan sehingga dapat mendorong berjalannya roda ekonomi. Rehabilitasi sosial berarti perbaikan suatu tempat harus dapat 
memberi dampak sosial positif dan mampu mewadahi public realm / publik (Danisworo, 2002).

Dalam merevitalisasi PSWG, maka yang ditempuh pertama adalah intervensi fisik. Menurut Martokusumo, ada 5 tahapan dalam intervensi fisik dan fungsional,(Martokusumo, 2008) yaitu tahap 1 berupa penyusunan rencana prioritas dengan Rencana Induk Kawasan (RIK) / Masterplan Kawasan. Tahap 2 yaitu penciptaan delineasi kawasan (batas kawasan). Tahap 3 yaitu proses analisis kawasan untuk mendapatkan kondisi fisik wilayah perencanaan, sesuai dengan RIK, RTBL yang berlaku. Tahap 4 adalah pengembangan ide konseptual dan terperinci. Tahap 5 adalah monitoring, evaluasi dalam tahap perencanaan, perancangan, dan pelaksanaan. Revitalisasi yang sukses dapat menciptakan pesatnya pertumbuhan ekonomi, sosial, budaya pada suatu tempat. Selain sebagai pendekatan untuk penyelesaian permasalahan di PSWG, harus dipertimbangkan dampak negatif dari revitalisasi adalah terjadinya gentrifikasi Gentrifikasi merupakan perubahan struktur urban berupa relokasi penduduk akibat revitalisasi.

\section{Konsep Desain}

Mitologi atau mitos termasuk dalam teori folklore. Folklore berasal dari dua kata yaitu folk dan lore. Definisi folk yaitu sekelompok orang yang memiliki ciri fisik, sosial, budaya yang sama sedangkan lore adalah pengetahuan. Menurut Jan Harold Brunvand (Danandjaja, 1986), terdapat 3 jenis folklore yaitu folklore lisan, folklore sebagian lisan, dan folklore non lisan. Konsep desain Segara Kidul yang terinspirasi dari Kanjeng Ratu Kidul merupakan folklore lisan berupa legenda.

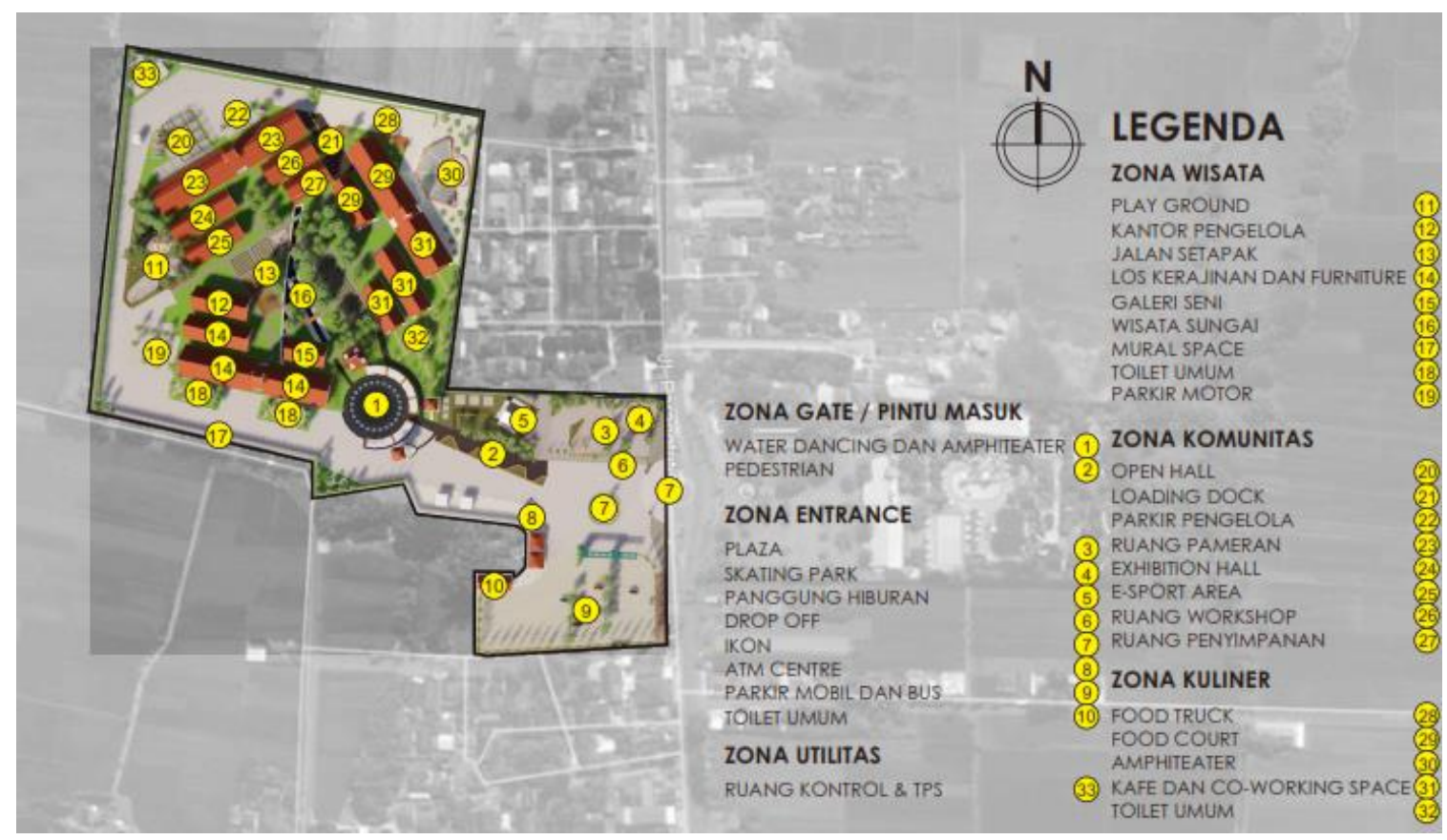

Gambar 12. Usulan Desain Masterplan Pasar Seni dan Wisata Gabusan

Melihat konteks lokasi Pasar Seni dan Wisata Gabusan, maka sebagai tempat transit yang terletak menuju Pantai Parangtritis sesuai dengan ide dan nuansa bahari. Segoro Kidul merupakan konsep yang ditawarkan untuk rebranding. Segoro artinya air, sungai, Kidul artinya selatan. Kanjeng Ratu Kidul adalah sosok dewi penguasa laut, berbeda dengan Nyi Roro Kidul yang merupakan jelmaan Dewi Nawangwulan (Murti, 2018). Kanjeng Ratu
Kidul diyakini warga setempat sebagai sosok yang menjaga kawasan pantai identik dengan warna hijau. Oleh karena itu, sangat tidak disarankan berpakaian hijau ke Pantai Selatan Yogyakarta untuk menghormati keberadaan Kanjeng Ratu Kidul. Mitologi Kanjeng Ratu Kidul yang merupakan sosok penjaga Pantai dan Laut Selatan Yogyakarta harus diangkat kembali sebagai salah satu kekayaan tradisi dan budaya lokal. Hal ini dapat menjadi salah satu bentuk 
kepedulian dan edukasi terhadap terjaganya lingkungan dan ekosistem pantai dan kawasan sekitarnya. Penataan kembali PSWG dengan membawa semangat awal desain serta menyesuaikan dengan konteks terkini dapat dilihat pada Gambar 12.

\section{Aplikasi Strategi Revitalisasi .}

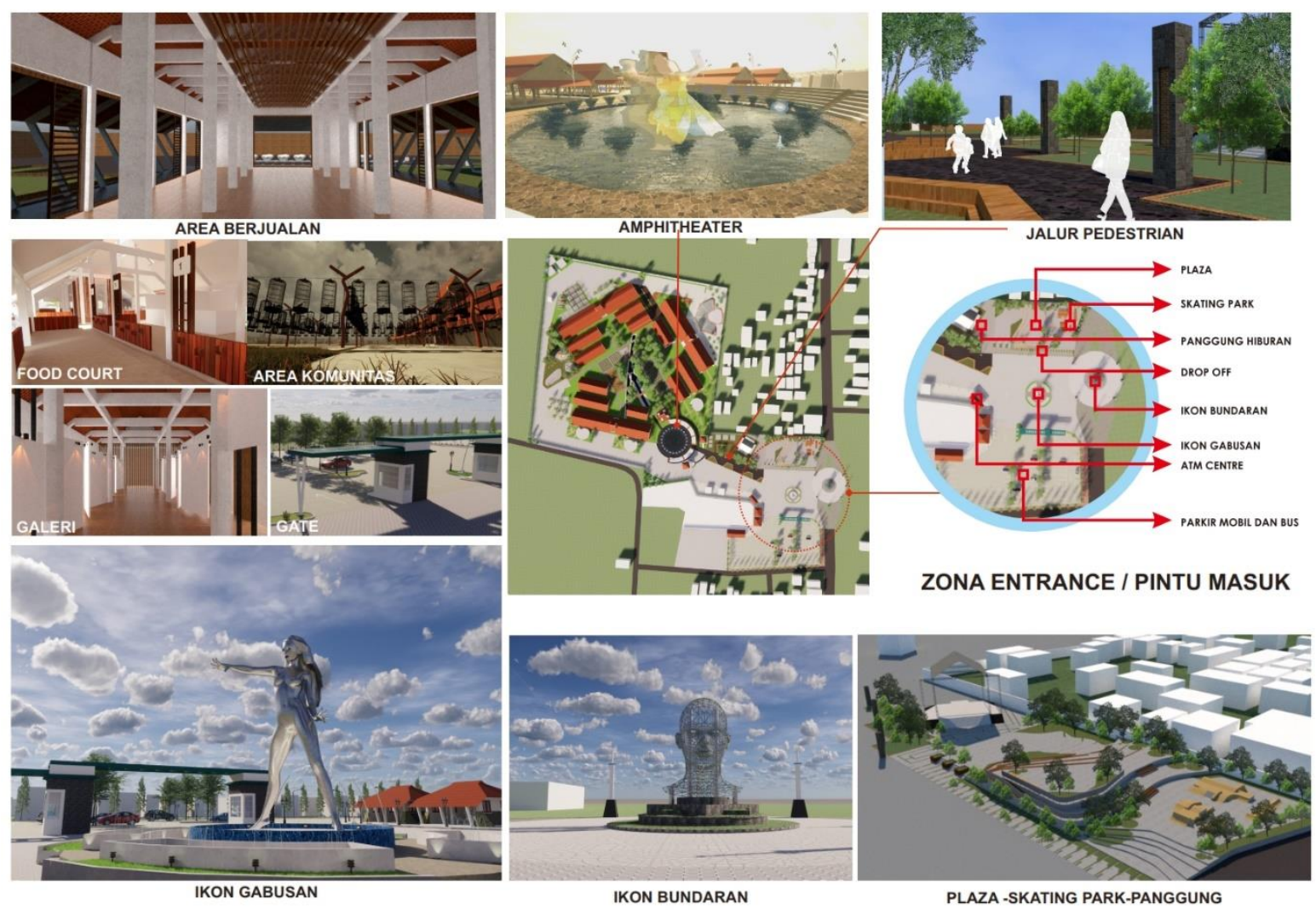

Gambar 13. Aplikasi Strategi Konsep Desain

Untuk mengoptimalkan kualitas visual PSWG maka revitalisasi harus dilakukan di beberapa titik berikut ini pada Gambar 13 sesuai hasil analisis site:

\section{a. Area Pintu Masuk (Entrance)}

Area ini meliputi sekitar 400 meter di sisi utara dan selatan sebagai area transisi dengan traffic calming, area bundaran, area gerbang pintu masuk, area pertokoan dan area eksisting signage tulisan Pasar Gabusan. Traffic Calming adalah strategi yang dapat digunakan untuk mereduksi kecepatan pengguna jalan hingga kurang dari 30 km/jam.(Wen, L., Kenworthy, J., \& Marinova, 2020). Traffic calming berfungsi untuk memusatkan konsentrasi pengunjung dan pengendara dengan teknik rekayasa sirkulasi dan lalu lintas. Traffic Calming dapat dicapai dengan menggunakan material pathway atau pelapis sirkulasi jalan yang kontras dan berbeda dari yang lain, serta memperkuat karakter pelingkup kanan dan kiri kawasan seperti merenovasi fasad bangunan, merenovasi tata vegetasi.

b. Tata Lanskap dan Vegetasi

Revitalisasi area ini meliputi penataan softscape berupa vegetasi, hardscape berupa pendukung lanskap seperti lapisan penutup jalan pedestrian dan pesepeda, serta area irigasi. Area irigasi sangat potensial untuk dijadikan fitur menarik di kompleks PSWG. Selain Area Irigasi, fitur air lainnya yaitu berupa air mancur yang dapat menjadi arena bermain anak dalam waktu tertentu. Wisata air dapat menjadi pengalaman yang menyenangkan bagi pengunjung dan terbukti ada peningkatan kualitas kesejahteraan setelah berkunjung ke tempat wisata berbasis alam(Folgado-Fernández, 
José Antonio; Di-Clemente, Elide; Hernández-Mogollón, José Manuel ; Campón-Cerro, 2018).

c. Tata Pencahayaan

Tata pencahayaan harus mengekspos bagian-bagian penting pada site seperti signage, landmark atau ikon PSWG yang baru, vegetasi, dan sirkulasi kawasan PSWG. Tata pencahayaan yang menarik dapat meningkatkan kualitas visual dan menarik lebih banyak pengunjung.

\section{d. Sirkulasi}

Ada beberapa sirkulasi di PSWG yaitu sirkulasi kendaraan bermotor: mobil, motor, bus, lalu sirkulasi pedestrian, dan sirkulasi pesepeda. Sesuai dengan hasil diskusi dengan Bappeda Bantul maka di PSWG harus dibuat sirkulasi yang jelas sehingga tidak saling tercampur dan terjadi kemacetan atau kerancuan zonasi. e. Fitur Arsitektural : Hologram Ikon Kawasan

Hologram adalah salah satu bentuk dari Augmented Reality (AR). AR memiliki beragam fungsi salah satunya digunakan sebagai sarana wisata yang dapat menyajikan situasi di masa lampau, masa mendatang, dan berinteraksi langsung dengan pengunjung (Krevelen, D.W.F. van;Poelman, 2010) AR telah banyak digunakan untuk meningkatkan pengalaman pengunjung yang dapat menciptakan memori yang berkesan (Tom Dieck, M. C., Jung, T., \& Rauschnabel, 2018). Sebagai salah satu fitur yang mendukung kemajuan jaman, maka teknologi hologram sebagai fitur pada PSWG yang baru harus dimunculkan. Fitur Hologram ini dapat dinikmati pada area amphitheater. Hologram dapat menampikan cerita rakyat, atau tokoh yang sangat berpengaruh di Kabupaten Bantul, Yogyakarta.

f. Pendekatan Segi Ekonomi dan Kerjasama

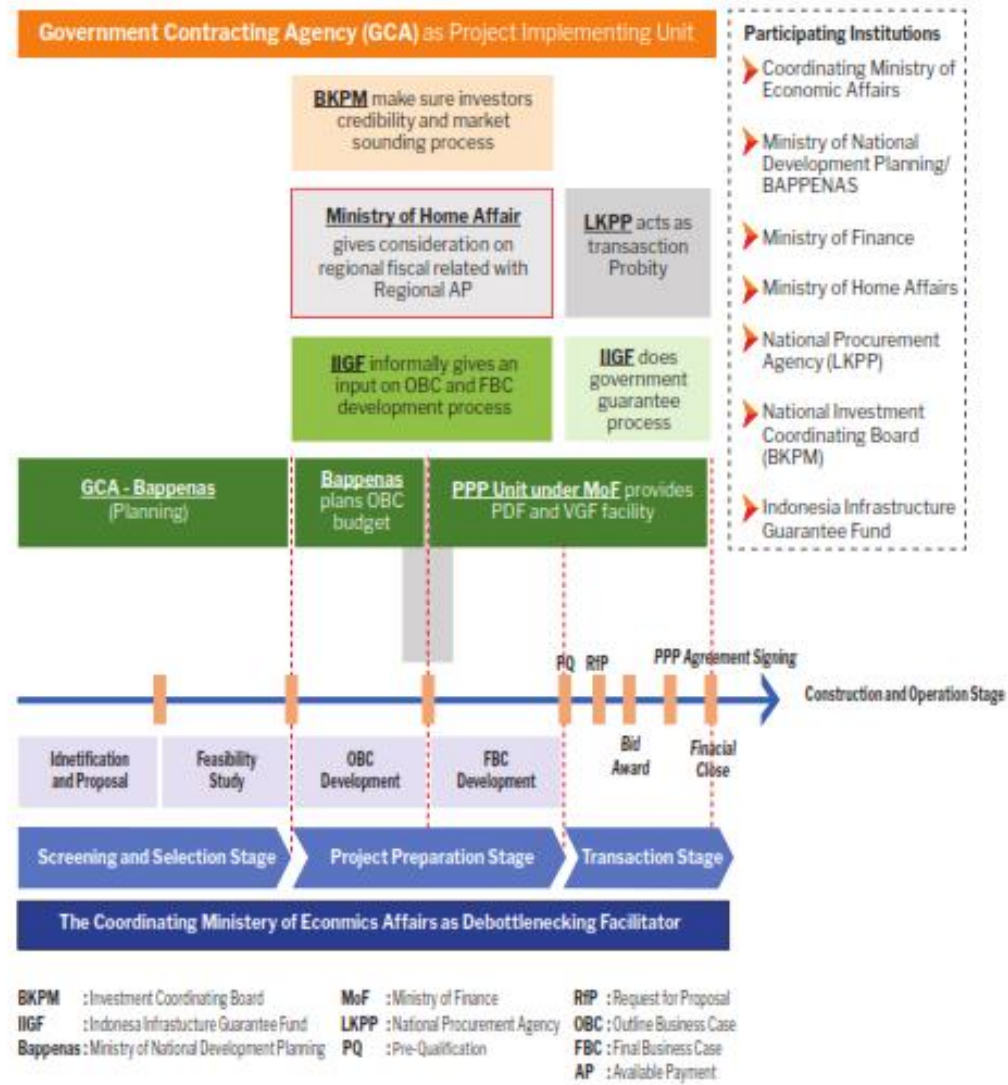

Gambar 14 Alur Kerja dengan Sistem Public Private Partnership (Bappenas, 2018) 
Pendekatan yang disarankan di PSWG untuk meminimalisasi dampak negatif adalah dengan public private partnership $(P P P)$. PPP adalah suatu skema kerjasama antara pemerintah dan swasta yang diselenggarakan dalam waktu tertentu dan perjanjian tertentu dalam suatu badan usaha (Lihat Gambar 14). Sistem PPP biasanya berlaku antara waktu 10-30 tahun dan ditujukan untuk proyek infrastuktur dan layanan publik. Sistem skema ini terbukti signifikan dalam menuai kesuksesan di beberapa proyek publik skala raksasa di Indonesia, contohnya: proyek jalan tol seperti Jalan Tol Balikpapan Samarinda, Jalan Tol Jakarta Cikampek II.

Sistem ini terhitung menguntungkan semua pihak yaitu swasta, pemerintah, dan masyarakat. Pemerintah sebagai penyelenggara dan pihak yang membuat badan usaha dengan pihak swasta yang diajak kerjasama serta memberikan dukungan finansial jika dibutuhkan. Sedangkan swasta memiliki tanggungjawab dan resiko yang diemban oleh pemerintah. Tanggungjawab dalam proses pembangunan berupa penyediaan finansial, tenaga ahli, dan teknologi. Selain itu pihak swasta juga dapat melakukan pemeliharaan jika dibutuhkan, dengan sistem kontrak. (Nurairinnisa, 2019). Selain dari segi ekonomi, kerjasama antara pemerintah dan komunitas terkait harus dimulai dan dijaga untuk mendukung keberhasilan revitalisasi. Program ini dapat berupa community development untuk mengetahui perkembangan dari rencana, tujuan, program, dan rencana di masa mendatang. (Putra \& Rudito, 2014)

\section{MANFAAT DAN PENINGKATAN BAGI MITRA}

Dengan terselesaikannya Masterplan

Revitalisasi Pasar Seni dan Wisata Gabusan ini, mitra mendapatkan pengetahuan mengenai alternatif pengembangan Pasar Seni yang berbasis pada rebranding Pasar Seni Gabusan menjadi Pasar Seni dan Wisata Gabusan. Berbagai alternatif telah dibahas sebagai bagian dari proses pemberdayaan mitra maupun dalam tim. Tim pengabdian dan mitra berproses bersama dengan memadukan keunggulan masing-masing merupakan bentuk pemberdayaan yang sangat menarik mengingat semua pihak ikut mengalami perkembangan pembelajaran bersama untuk menemukan solusi kreatif inovatif.

Masterplan Pasar Seni dan Wisata Gabusan ini merupakan salah satu elemen yang digunakan untuk menjaring dana dari berbagai pihak serta merupakan syarat untuk penyusunan produk perencanaan berikutnya yaitu penyusunan DED (Detail Engineering Design) yang diperlukan untuk menghitung kebutuhan dana pembangunan fisik PSWG.

\section{SIMPULAN DAN SARAN}

Sebagai kesimpulan, Pasar Seni dan Wisata Gabusan (PSWG) sangat berpotensi untuk menjadi salah satu destinasi wisata di Yogyakarta. Namun hal ini harus didukung dengan perbaikan dan memperkuat branding atau image PSWG bagi kawasan dengan revitalisasi. Pengabdian ini terbatas pada perbaikan secara fisik dan visual dengan identifikasi kelima elemen kawasan Lynch sehingga untuk terwujud suksesnya visi misi PSWG maka dari pihak manajemen PSWG, Pemerintah Kabupaten Bantul, dan pelaku wisata harus saling bekerjasama.

Saran untuk pengembangan PSWG adalah dilakukannya feasibility study yang lebih mendalam, sehingga revitalisasi dan rebranding Pasar Seni dan Wisata Gabusan dapat terlaksana dengan tepat sasaran. Untuk mewujudkan riset, dan pelaksanaan yang tepat, dibutuhkan perencanaan yang matang dari seluruh aspek, yaitu waktu, budget, dan tenaga ahli yang tepat.

\section{UCAPAN TERIMAKASIH}

Pengabdian ini dapat berjalan baik atas kerjasama dan bantuan berbagai pihak. Untuk itu penulis menyampaikan dan terimakasih disampaikan kepada Bappeda Kabupaten Bantul sebagai mitra kerjasama Pengabdian kepada Masyarakat, LPPM UAJY sebagai pemberi fasilitas pengabdian dan penelitian dalam bentuk bantuan dana, serta Tim Mahasiswa dan Peneliti Pasar Seni dan Wisata Gabusan. 


\section{DAFTAR PUSTAKA}

PERATURAN DAERAH KABUPATEN BADUNG NOMOR 26 TAHUN 2013 TENTANG RENCANA TATA RUANG WILAYAH KABUPATEN BADUNG TAHUN 2013 - 2033, e-conversion Proposal for a Cluster of Excellence 1 (2018).

BPS KabupatenBantul. (2020). Kabupaten Bantul dalam Angka 2020. BPS Kabupaten Bantul.

Danandjaja, J. (1986). Folklor Indonesia: Ilmu Gosip, Dongeng, dan Lain-lain. PT.Pustaka Graffitipers.

Danisworo, M. (2002). Revitalisasi Kawasan Kota: Sebuah Catatan dalam Pengembangan dan Pemanfaatan Kawasan Kota. URDI, 13.

Departemen Perhubungan. (2004). Keputusan Menteri Perhubungan Nomor: KM 20 Tahun 2004 Tentang Penetapan Kelas Jalan Di Propinsi Bali, Nusa Tenggara Barat, Nusa Tenggara Timur, Maluku Utara, Dan Papua (p. 25).

Folgado-Fernández, José Antonio ; Di-Clemente, Elide ; Hernández-Mogollón, José Manuel; Campón-Cerro, A. M. (2018). Water tourism: A new strategy for the sustainable management of water-based ecosystems and landscapes in Extremadura (Spain). Land, 8(1). https://doi.org/10.3390/land8010002

Ikatan Arsitek Indonesia., P. R. (2005). Karya Arsitek Indonesia (Y. S. Sutrisno, Bambang., Sukada, Budi Adelar., Sulistiono (ed.)). PT.Printindo Utama.

Kompas. (2009). Pasar Seni Gabusan Terancam Bubar.

https://megapolitan.kompas.com/read/2009/ 05/13/19083570/pasar.seni.gabusan.bantul.t erancam.bubar

Krevelen, D.W.F. van;Poelman, R. (2010). A Survey of Augmented Reality Technologies, Applications and Limitations. The International Journal of Virtual Reality, 2010, 9(2):1-20, 19. https://doi.org/10.1155/2011/721827

Lynch, K. (1960). The Image of The City. The MIT Press.
Martokusumo, W. (2008). Revitalisasi, Sebuah Pendekatan dalam Peremajaan Kawasan. Jurnal Perencanaan Wilayah Dan Kota, 19 / No.3(Desember 2008), 57-73.

McCunn, L. J., \& Gifford, R. (2018). Spatial Navigation and Place Imageability in Sense of Place. Cities, 74, 208-218.

Murti, N. D. (2018). TRADISI BEKTI PERTIWI PISUNGSUNG JALADRI: Program Studi Sastra Indonesia Fakultas Sastra Universitas Sanata Dharma Yogyakarta [Universitas Sanata Dharma Yogyakarta]. https://repository.usd.ac.id/19294/2/144114 009_full.pdf

Nurairinnisa, Y. (2019). Mengenal "Public Private Parthnership." Kompasiana. https://www.kompasiana.com/18191050100 9yustinanura/5cf34a3fc01a4c499367e91b/ mengenal-public-privatepartnership?page $=$ all

PekerjaanUmum, M. (2010). Permen PU No. 18 Tahun 2010 tentang Pedoman Revitalisasi Kawasan.

Putra, R. D. D., \& Rudito, B. (2014). Community Development Planning of Pt Elva Primandiri' $S$ Revitalization of Limbangan Traditional Market Projet. 3(1), 81-88.

Suryowati, E. (2016). Berapa Pasar Tradisional yang Sudah Dibenahi Pemerintah pada 2016? Kompas.Com. https://money.kompas.com/read/2017/01/05 /074400126/berapa.pasar.tradisional.yang.s udah.dibenahi.pemerintah.pada.2016.?page $=$ all

Tom Dieck, M. C., Jung, T., \& Rauschnabel, P. A. (2018). Determining visitor engagement through augmented reality at science festivals: An experience economy perspective. Computers in Human Behaviour, $\quad 82, \quad 44-53$. https://doi.org/https://doi.org/10.1016/j.chb. 2017.12.043

Wen, L., Kenworthy, J., \& Marinova, D. (2020). Higher Density Environments And The Critical Role Of City Streets As Public Open Spaces. MDPI, 12(27 October 2020), 1-34.

https://doi.org/doi:10.3390/su12218896 